\title{
Wound Healing and Anti-Inflammatory Activity of Methanolic Extract of Gmelina arborea and Hemigraphis colorata in Rats
}

\author{
Bhagyalakshmi Chengattu Prakashbabu ${ }^{1}$, Deepthi Vijay ${ }^{1}$, Saju George ${ }^{1}$, \\ Sameer Kodiyil ${ }^{1}$, Suresh Narayanan Nair ${ }^{*}$, Ajithkumar Karaparambil Gopalan², \\ Sanis Juliet ${ }^{1}$ and Reghu Ravindran ${ }^{2}$ \\ ${ }^{1}$ Department of Veterinary Pharmacology and Toxicology, ${ }^{2}$ Department of Veterinary \\ Parasitology, College of Veterinary and Animal Sciences, \\ Pookode, Wayanad- Kerala-673576, India \\ *Corresponding author
}

\author{
A B S T R A C T
}

\section{Keywords}

Gmelina arborea,

Hemigraphis

colorata, Excisional

wound healing,

Carageenan induced

paw oedema.

Article Info

Accepted:

26 June 2017

Available Online:

10 August 2017
Gmelina arborea and Hemigraphis colorata are traditionally used by tribal healers of Wayanad district, Kerala India. The wound healing and anti-inflammatory activity of Gmelina arborea and Hemigraphis coloratawere tested in adult wistar albino rats. Wound healing activity was assessed using excisional wound healing method and antiinflammatory activity was assessed using carageenan induced paw oedema model. Acute oral toxicity of the extract was determined by giving the extract at the rate of $2000 \mathrm{mg} / \mathrm{kg}$ by single oral dose. For testing the wound healing activity, the methanolic extracts of the plants were used at 5\% and $10 \%$ in paraffin vehicle and the effect was compared with the standard drug boric acid. Anti-inflammatory activity was assessed by single oral dose at the rate of $250 \mathrm{mg} / \mathrm{kg}$ and $500 \mathrm{mg} / \mathrm{kg}$ of the extracts subsequent to carageenan, keeping diclofenac as positive control. It was found that both plant extract did not possess any significant toxicity after oral dosing. $H$. colorata showed excellent wound healing activity and G. arborea showed moderate activity. With respect to the anti-inflammatory activity, $G$ arborea was having better activity than $H$ colorata extract, though both were significantly less effective than diclofenac. Both the plant extract showed significant wound healing as well as anti-inflammatory activities.

\section{Introduction}

Wound is defined as disruption of cellular, anatomical, and functional continuity of a living tissue. It may be produced by physical, chemical, thermal, microbial, or immunological insult to the tissue. Optimum healing of a cutaneous wound requires a wellorchestrated integration of the complex biological and molecular events of cell migration and proliferation and of extracellular matrix deposition and remodelling (Yusof, 2005). Inflammation is a complex biological response of vascular tissue to harmful stimuli, pathogens, irritants characterized by redness, warmth, swelling and pain (Palladino et al., 2003).

Large group of medicinal plants are used as traditional medicine, which have potential to cure various ailments. These medicinal plants which contain potential sources of phyto 
compounds are used for many therapeutic purposes (Murugesan and Deviponnuswamy, 2014). Plants have the immense potential for the management and treatment of wounds. A large number of plants are used by tribal and folklore in many countries for the treatment of wounds and burns. These natural agents induce healing and regeneration of the lost tissue by multiple mechanisms. These phytomedicine are not only cheap and affordable but are also safe (Thakur et al., 2011).

Gmelina arborea, (Beechwood), is a fastgrowing medium to large deciduous treethat reaches $35 \mathrm{~m}$ in height and more than $3 \mathrm{~m}$ in diameter, occurring naturally throughout greater part of India at altitudes up to 1,500 meters. Also its presence is noted in Bangladesh, China, Pakistan, Myanmar, Nepal, Vietnam, Thailand, and Sri Lanka (Dvorak, 2004). It is found to possess in vitro antioxidant (Patil et al., 2009), hepato protective (Sinha et al., 2006), anti-diabetic (Kulkarni et al., 2013), insecticidal (Vitrata and Tomentosicollis, 2005) and anti-bacterial activities (El-Mahmood et al., 2010).

Hemigraphis colorata (Acanthaceae), an exotic plant adapted to India, is a versatile tropical low-creeping perennial herb that reaches a height of 15 to $30 \mathrm{~cm}$. It prostrates and spreads with rooting stems when grown on ground. The leaf has metallic purple lustre on upper surface and a solid dark purple on ventral side. The leaves are opposite, ovate to cordate, serrate-crenate, about 2 to $8 \mathrm{~cm}$ long and 4 to $6 \mathrm{~cm}$ wide, bearing well-defined veins (Priya, 2012). This plant is found to have antibacterial (Anithaet al., 2012; Jayaprakasan et al., 2014), anti-elastase activity (Gangadharan et al., 2013) and antioxidant (Akhil and Prabhu, 2013). Detailed pharmacognostical and phytochemical study of the plant was done by Saravanan et al., (2010).
The above mentioned plants are used by tribal and folklore healers for the treatment of inflammation and wound in the Wayanad district of Kerala. Hence a study was conducted to systematically evaluate the wound healing activity and anti-inflammatory screening of this plant in appropriate rat models.

\section{Materials and Methods}

Adult healthy male wistar albino rats of 6 months of age weighing 200-250g were used for the study. Animals were maintained under uniform standard managemental condition at the institutional laboratory animal facility. Animals were given standard rat feed. Clean water was provided ad lib. The experiments were approved by the institutional animal ethics committee of the institute.

The plants Gmelina arborea and Hemigraphis coloratawere collected locally and were identified by a botanist. The aerial parts were washed and dried in shade, pulverised and kept in air tight container at room temperature till extraction.

\section{Preparation of methanolic extract}

Pulverised plant was extracted with methanol in a soxhlet extraction unit at $70^{\circ} \mathrm{C}$ successively for five times. Methanol was removed by rotary vacuum evaporator $(\mathrm{M} / \mathrm{s}$ Buchi, Switzerland) and dried till entire methanol was evaporated.

\section{Acute oral toxicity of the extracts}

Acute oral toxicity of the extracts were assessed according to OECD 425 guidelines at limit dose of $2000 \mathrm{mg} / \mathrm{kg}$ body weight give orally as a single dose for three animals. The animals were observed for any morbidity and mortality upto 14 days and at $15^{\text {th }}$ day the animals were slaughtered humanely and the 
organs were examined for any pathological changes.

\section{Wound healing activity}

Excisional wound healing method as described by Morton and Malone (1972) was used for the assessment. Animals were divided into six groups of six animals each based on the treatment done or the wounded area, as given below

Group I Control: - White soft paraffin

Group II Standard drug: $10 \%$ boric acid in white soft paraffin

Group III: Test extract Gmelina arborea 5\% in white soft paraffin

Group IV: Test extract Gmelina arborea 10\% in white soft paraffin

Group V: Test extract Hemigraphis colorata $5 \%$ in white soft paraffin

Group VI: Test extract Hemigraphis colorata $10 \%$ in white soft paraffin

After the animals were anaesthetized dorsal fur was shaved and a full thickness of the excision wound of $1 \mathrm{~cm}^{2}$ was created along the markings using a surgical blade and pointed scissors. The entire wound was left open. The wound closure rate was assessed by tracing the wound on days all days till it healed, using transparency paper and a permanent marker. The wound areas recorded were traced to a graph paper and the area was measured. Number of days required for falling of eschar without any residual raw wound gave the period of epithelisation. The reduction in wound area on everyday was calculated using the formula $\%$ reduction in wound area on $n^{\text {th }}$ day $=\left(\right.$ initial wound area - wound area on $n^{\text {th }}$ day) X 100/ initial wound area.

\section{Anti-inflammatory activity}

Anti-inflammatory activity was measured using carrageenan induced paw oedema in rats (Morris, 2003). Animals were divided into six groups of six animals each, as given below

Group I Control: - Distilled water

Group II Standard drug - Diclofenac 30 $\mathrm{mg} / \mathrm{kg}$ oral

Group III: Test extract - Gmelina arborea 250 $\mathrm{mg} / \mathrm{kg}$ in water

Group IV: Test extract - Gmelina arborea 500 $\mathrm{mg} / \mathrm{kg}$ in water

Group V: Test extract - Hemigraphis colorata $250 \mathrm{mg} / \mathrm{kg}$ in water

Group VI: Test extract - Hemigraphis colorata $500 \mathrm{mg} / \mathrm{kg}$ in water

Paw thickness was measured using vernier callipers. The basal paw thickness was measured before the administration of inflammatory agent. Carrageenan (M/s HiMedia, India) $1 \% \mathrm{w} / \mathrm{v}$ was dissolved in $0.9 \%$ normal saline solution and was given as sub-plantar injection using $25 \mathrm{G}$ needle to the right hind paw of each animal.

Paw volume was measured at 1, 2, 3 and 4 hours and the increase in paw volume was calculated by subtracting the basal paw thickness. The percentage increase in paw thickness was calculated as \% increase = (Volume at $\mathrm{n}^{\text {th }}$ hour- basal volume) X100/ Basal volume.

The results were analysed statistically using SPSS and Tukey's post-hoc tests for significance at $5 \%$ and the results are expressed as mean \pm SEM. 


\section{Results and Discussion}

\section{Acute oral toxicity of the extracts}

Upon administration of the extract at the dose rate of $2000 \mathrm{mg} / \mathrm{kg}$, no deaths were observed in any of the extract group. This result indicates that there is no acute oral toxicity for the drug even at limit test dose of OECD 425 guideline. Hence this extract can be considered as practically non-toxic.

\section{Wound healing activity}

The results of reduction in wound area in excisional wound healing model are given in table 1. The result showed that both the extracts possess wound healing activity when compared to the control drug. Among them, $H$. colorata had better wound healing activity especially at the higher dose of $10 \%$ ointment as compared to even boric acid. From the day 4 , the effect was better than the boric acid as given by the reduction of wound area by $58.12 \pm 3.76 \%$ in boric acid treated group while the reduction in wound area was59.15 \pm $2.12 \%$. The complete wound healing was observed two days earlier (seventh day) in $H$. colorata $10 \%$ group and boric acid group, one day earlier (eighth day) in all other groups except the lower concentration of G. arborea $5 \%(98.12 \pm 3.23)$. The general effect of $G$. arborea was less than that of $H$ colorata and boric acid, but was superior to that of control. On visual observation, all the treatment groups with plant extracts were having less visible signs of inflammation than the control as well as the boric acid groups.

\section{Anti-inflammatory activity}

The results of reduction in wound area in excisional wound healing model are given in table 2. From the result it is clear that both the extracts possessed significant antiinflammatory activity than the control group, the effect being more for $G$ arborea than $H$ colorata. But both the extracts were having lower effect than the standard drug diclofenac. The acute anti-inflammatory effect was less than that of diclofenac as indicated by a lower value of reduction in paw thickness of $10.23 \pm 2.21$ and $15.65 \pm$ 2.76 respectively for $G$. arborea $250 \mathrm{mg} / \mathrm{kg}$ and $500 \mathrm{mg} / \mathrm{kg}$ and $7.56 \pm 1.43$ and $11.45 \pm$ 2.09 respectively for $H$. colorata $250 \mathrm{mg} / \mathrm{kg}$ and $500 \mathrm{mg} / \mathrm{kg}$, whereas it was $20.12 \pm 1.45$ for diclofenac. However, during the third hour of inflammation, the effect was comparatively better for both plant extracts. By fourth hour there was more than $50 \%$ resolution of inflammation in diclofenac group (79.11 \pm $2.11), G$ arborea $500 \mathrm{mg} / \mathrm{kg}(62.16 \pm 2.12)$ and $H$ colorata $500 \mathrm{mg} / \mathrm{kg}(54.33 \pm 2.76)$.

In the present study it was found that both the plant extracts are having a significant wound healing as well as anti-inflammatory activity. $H$. colorata was having excellent wound healing activity which excels the standard drug boric acid. G. arborea also possess a good wound healing activity when compared to the negative group. Regarding the antiinflammatory activity, G. arborea is better in its action compared to $H$. colorata, but the anti-inflammatory activity is significantly less for both the extracts when compared to the standard drug diclofenac.

Considering the fact that nearly 6 million people suffer from chronic wounds worldwide, wounds particularly chronic wounds are major concerns for the patient as well as for clinician as they seriously reduce their quality of life (Kumar et al., 2007).

Wound healing is an intricate process initiated in response to an injury that restores the integrity and function of damaged tissues, which involves continuous cell-cell and cellmatrix interactions allowing to proceed in three overlapping phases viz. inflammation 
(0-3days), cellular proliferation (3-12 days) and remodelling (3-6months) (Clark, 1996). Wound healing is complete when the disrupted surfaces are firmly knit by collagen and the process involves platelet aggregation and blood clotting, formation of fibrin, alteration in the ground substances, angiogenesis andre-epithelialisation (Buffoni, 1993).

Table.1 Wound healing activity of methanolic extract of G. arborea and H.colorata in excisional Wound healing model (Mean \% reduction in wound area \pm SEM)

\begin{tabular}{|l|l|l|l|l|l|l|l|l|l|}
\hline & Day 1 & Day 2 & Day 3 & Day 4 & Day 5 & Day 6 & Day 7 & Day 8 & Day 9 \\
\hline Control & 5.98 & $11.98 \pm$ & $18.34 \pm$ & $28.17 \pm$ & $36.17 \pm$ & $59.93 \pm$ & $76.12 \pm$ & $89.55 \pm$ & \\
& $\pm 1.98^{\mathrm{a}}$ & $1.56^{\mathrm{a}}$ & $1.95^{\mathrm{a}}$ & $2.59^{\mathrm{a}}$ & $1.09^{\mathrm{a}}$ & $3.98^{\mathrm{a}}$ & $2.96^{\mathrm{a}}$ & $2.74^{\mathrm{a}}$ & $100 \pm 0$ \\
\hline Boric & $14.91 \pm$ & $29.34 \pm$ & $43.34 \pm$ & $58.12 \pm$ & $69.12 \pm$ & $91.23 \pm$ & & & \\
acid & $2.11^{\mathrm{c}}$ & $1.06^{\mathrm{c}}$ & $1.98^{\mathrm{c}}$ & $3.76^{\mathrm{c}}$ & $1.58^{\mathrm{c}}$ & $3.22^{\mathrm{b}}$ & $100 \pm 0^{\mathrm{b}}$ & $100 \pm 0^{\mathrm{b}}$ & $100 \pm 0$ \\
\hline GA 5\% & $9.24 \pm$ & $16.25 \pm$ & $29.23 \pm$ & $35.12 \pm$ & $49.99 \pm$ & $75.12 \pm$ & $85.45 \pm$ & $98.12 \pm$ & \\
& $1.23^{\mathrm{b}}$ & $2.12^{\mathrm{b}}$ & $2.12^{\mathrm{b}}$ & $2.25^{\mathrm{b}}$ & $2.23^{\mathrm{b}}$ & $1.67^{\mathrm{b}}$ & $2.29^{\mathrm{b}}$ & $3.23^{\mathrm{b}}$ & $100 \pm 0$ \\
\hline GA10\% & $12.98 \pm$ & $19.98 \pm$ & $35.34 \pm$ & $43.17 \pm$ & $56.17 \pm$ & $89.93 \pm$ & $96.12 \pm$ & & \\
& $1.03^{\mathrm{c}}$ & $1.15^{\mathrm{b}}$ & $1.33^{\mathrm{c}}$ & $1.85^{\mathrm{c}}$ & $3.22^{\mathrm{b}}$ & $2.65^{\mathrm{b}}$ & $3.12^{\mathrm{b}}$ & $100 \pm 0$ & $100 \pm 0$ \\
\hline HC 5\% & $11.34 \pm$ & $20.11 \pm$ & 34.94 & $42.47 \pm$ & $53.97 \pm$ & $82.15 \pm$ & $98.12 \pm$ & & \\
& $0.98^{\mathrm{bc}}$ & $1.76^{\mathrm{b}}$ & $\pm 1.15^{\mathrm{c}}$ & $3.11^{\mathrm{c}}$ & $1.03^{\mathrm{b}}$ & $1.67^{\mathrm{b}}$ & $1.87^{\mathrm{b}}$ & $100 \pm 0^{\mathrm{b}}$ & $100 \pm 0$ \\
\hline HC 10\% & $13.45 \pm$ & $28.12 \pm$ & $42.65 \pm$ & $59.15 \pm$ & $72.12 \pm$ & $96.12 \pm$ & & & \\
& $2.12^{\mathrm{c}}$ & $1.04^{\mathrm{c}}$ & $0.98^{\mathrm{c}}$ & $2.12^{\mathrm{c}}$ & $1.26^{\mathrm{c}}$ & $3.22^{\mathrm{b}}$ & $100 \pm 0$ & $100 \pm 0$ & $100 \pm 0$ \\
\hline
\end{tabular}

One way ANOVA with Tukey's post hoc analysis. Values with different superscripts vary significantly

Table.2 Anti-inflammatory activity of methanolic extract of G. arborea and H.colorata in Carageenan induced paw oedema (Mean \% reduction in inflammation \pm SEM)

\begin{tabular}{|l|l|l|l|l|}
\hline & $1 \mathrm{hr}$ & $2 \mathrm{hrs}$ & $3 \mathrm{hrs}$ & $4 \mathrm{hrs}$ \\
\hline Diclofenac & $20.12 \pm 1.45^{\mathrm{c}}$ & $42.34 \pm 2.21^{\mathrm{c}}$ & $63.55 \pm 1.98^{\mathrm{c}}$ & $79.11 \pm 2.11^{\mathrm{c}}$ \\
\hline GA $250 \mathrm{~kg} / \mathrm{kg}$ & $10.23 \pm 2.21^{\mathrm{b}}$ & $23.11 \pm 1.12^{\mathrm{ab}}$ & $34.77 \pm 1.22^{\mathrm{a}}$ & $49.22 \pm 1.19^{\mathrm{a}}$ \\
\hline GA $500 \mathrm{mg} / \mathrm{kg}$ & $15.65 \pm 2.76^{\mathrm{b}}$ & $29.45 \pm 2.77^{\mathrm{b}}$ & $51.44 \pm 2.44^{\mathrm{b}}$ & $62.16 \pm 2.12^{\mathrm{b}}$ \\
\hline HC $250 \mathrm{mg} / \mathrm{kg}$ & $7.56 \pm 1.43^{\mathrm{a}}$ & $17.54 \pm 1.87^{\mathrm{a}}$ & $35.11 \pm 2.01^{\mathrm{a}}$ & $43.12 \pm 3.15^{\mathrm{a}}$ \\
\hline HC $500 \mathrm{mg} / \mathrm{kg}$ & $11.45 \pm 2.09^{\mathrm{b}}$ & $25.58 \pm 2.22^{\mathrm{b}}$ & $45.22 \pm 3.11^{\mathrm{ab}}$ & $54.33 \pm 2.76^{\mathrm{a}}$ \\
\hline
\end{tabular}

One way ANOVA with Tukey's post hoc analysis. Values with different superscripts vary significantly

One of the major pathology of wound is the inflammation associated with it, which is the major cause of irritation in the wound.

Inflammation results in a coordinated influx of neutrophils at the site of wound and through their characteristic "respiratory burst" activity start producing free radicals (Baboir, 1978). Hence, an agent which is simultaneously having the wound healing and anti-inflammatory effect will be an excellent remedy in the management of wounds. The respiratory burst at the local area cause an elevated reactive oxygen species and reactive nitrogen species at the local site of wound, which will in excess can cause severe oxidative damage to the skin itself, including both cellular and extra cellular elements.

To accelerate wound healing and diminish the risk of tissue damage induced inflammation, exogenous substances, it is better to apply 
substances which could interfere with woundassociated ROS (RNS)-mediated processes (Korkina et al., 2007).

The concept of developing drugs from herbs in indigenous medical system is much older, while in some cases direct links between a local and biomedical use exists, in some other cases the relationship is more complex (Heinrich and Gibbons, 2001).

In the present study, it is established that both the compounds were having wound healing as well as anti-inflammatory activity. Previously, Patil et al., (2009) reported the antioxidant effect of $G$. arborea and Annan and Houghton (2008) reported the antioxidant activity of $H$. colorata.

Since the plant extracts are having all the qualities required for a wound healing and anti-inflammatory drug, it is safe to presume that this indigenous knowledge is a valid one and it can be safely used, considering its lack of toxicity for mammalian systems.

\section{Conflict of Interest}

The authors declare that there is no conflict of interest regarding the publication of this research paper.

\section{Acknowledgements}

Financial supports from Indian Council of Agricultural Research (ICAR) through research projects (NAIP/C2066, NFBSFARA/BSA-4004/2013-14, NASF/ ABA-6015/2016-17, No. 7(2)/- 2011- EPD) and National Bank for Agriculture and Rural Development G.O.(Rt)No.100/12/ AD RIDF XVI KERALA) are thankfully acknowledged.

\section{References}

Akhil, T.T. and Prabhu, P. 2013. Evaluation of anti-oxidant, anti-inflammatory and cytotoxicity potential of Hemigraphis colorata. International Journal of
Pharmaceutical Sciences and Research, 4(9), p.3477.

Anitha, V.T., Marimuthu, J. and Jeeva, S. 2012. Anti-bacterial studies on Hemigraphis colorata (Blume) HG Hallier and Elephantopus scaber L. Asian Pacific journal of tropical medicine, 5(1), pp.5257.

Annan, K. and Houghton, P.J., 2008. Antibacterial, antioxidant and fibroblast growth stimulation of aqueous extracts of Ficus asperifolia Miq. And Gossypium arboreum L., wound-healing plants of Ghana. Journal of Ethnopharmacology, 119(1), pp.141-144.

Baboir, B.M., 1978. Oxygen dependent microbial killing by phagocytes (first of two parts). N Engl J Med, 298, pp.629-68.

Buffoni, F., Bancheli, G., Cambi, S., Ignesti, G., Irisind, R., Raimondi, L., Vannelli,G., 1993. Skinwound healing: some biochemical parameters in Guineapig. Journal of Pharmaceutics and Pharmacology 45, 784-790.

Clark, R.A.F., 1996. Wound repair: overview and general consideration. In: Clark, R.A., Henson, P.M. (Eds.), Molecular and Cellular Biology of Wound Repair. The Plenum Press, New York.

Dvorak, W.S., 2004. World view of Gmelina arborea: opportunities and challenges. New Forests, 28(2-3), pp.111-126.

El-Mahmood, A.M., Doughari, J.H. and Kiman, H.S., 2010. In vitro antimicrobial activity of crude leaf and stem bark extracts of Gmelina arborea (Roxb) against some pathogenic species of Enterobacteriaceae. African Journal of Pharmacy and Pharmacology, 4(6), pp.355-361.

Gangadharan, A., Nishath, T.K. and Benny, P.J., 2013. Evaluation of phytochemical analysis, anti-oxidant and anti-elastase activity of Hemigraphis colorata. International Journal of Pharmacognosy and Phytochemical Research, 5(4), pp.292298.

Heinrich, M. and Gibbons, S., 2001. ISSN 0022-3573 Ethnopharmacology in drug discovery: an analysis of its role and 
potential contribution. JPP, 53, pp.425432.

Jayaprakasan, M.V., Viswanathan, K., Rajesh, M. and Pradymnan, P.P., 2014. Ayurvedic preparation from Azadirachta indica, Terminalia chebula, Hemigraphis colorata extracts and its antimicrobial investigation. IOSR Journal of Pharmacy and Biological Sciences, 9(2), pp.01-06.

Korkina, L.G., Mikhal'Chik, E., Suprun, M.V., Pastore, S. and Dal Toso, R., 2007. Molecular mechanisms underlying wound healing and anti-inflammatory properties of naturally occurring biotechnologically produced phenylpropanoid glycosides. Cell Mol Biol, 53(5), pp.84-91.

Kulkarni, Y.A. and Veeranjaneyulu, A., 2013. Effects of Gmelina arborea extract on experimentally induced diabetes. Asian Pacific journal of Tropical Medicine, 6(8), pp.602-608.

Kumar, B., Vijayakumar, M., Govindarajan, R. and Pushpangadan, P., 2007. Ethnopharmacological approaches to wound healing-exploring medicinal plants of India. Journal of Ethnopharmacology, 114(2), pp.103-113.

Murugesan, D. and Deviponnuswamy, R., 2014. Potential anti-inflammatory medicinal plants-a review. Int J Pharm Pharm Sci, 6(4), pp.43-49

Palladino MA, Bahjat FR, Theodorakis EA, Moldawer LLAnti-TNF- $\alpha$ therapies: the next generation. Nat Rev Drug Discovery2003; 2:736-746

Patil, S.M., Kadam, V.J. and Ghosh, R., 2009. In vitro antioxidant activity of methanolic extract of stem bark of Gmelina arborea Roxb. (Verbenaceae). International Journal of PharmTech Research, 1(4), pp.1408-84.

Patil, S.M., Kadam, V.J. and Ghosh, R., 2009. In vitro antioxidant activity of methanolic extract of stem bark of Gmelina arborea Roxb. (Verbenaceae). International Journal of PharmTech Research, 1(4), pp.1408-84.

Priya, M.D., 2012. Review on pharmacological activity of Hemigraphis colorata (Blume) HG Hallier. Mol Med, 3, pp.1-3.

Saravanan, J., Shariff, W.R., Joshi, N.H., Varatharajan, R., Joshi, V.G. and Karigar, A.A., $2010 . \quad$ Preliminary Pharmacognostical and Phytochemical Studies of Leaves of Hemigraphis colorata. Research Journal of Pharmacognosy and Phytochemistry, 2(1), pp.15-17.

Sinha, S., Dixit, P., Bhargava, S., Devasagayam, T.P.A. and Ghaskadbi, S., 2006. Bark and fruit extracts of Gmelina arborea. Protect liver cells from oxidative stress. Pharmaceutical biology, 44(4), pp.237-243.

Thakur, R., Jain, N., Pathak, R. and Sandhu, S.S., 2011. Practices in wound healing studies of plants. Evidence-Based Complementary and Alternative Medicine, 2011.

Vitrata, M. and Tomentosicollis, C., 2005. Studies on insecticidal potential of extracts of gmelina arborea products for control of field pests of cowpea, Vigna unguiculata (1.) Walp: the pod borer. Journal of Plant Protection Research, 45, p.1

Yusof, A.A., 2005. The effects of Carica papaya Linn. Latex on the healing of burn wounds in rats. Jurnal Sains Kesihatan Malaysia, 3(2), pp.39-47.

\section{How to cite this article:}

Bhagyalakshmi Chengattu Prakashbabu, Deepthi Vijay, Saju George, Sameer Kodiyil, Suresh Narayanan Nair, Ajithkumar Karaparambil Gopalan, Sanis Juliet and Reghu Ravindran. 2017. Wound Healing and Anti-Inflammatory Activity of Methanolic Extract of Gmelina arborea and Hemigraphis colorata in Rats. Int.J.Curr.Microbiol.App.Sci. 6(8): 3116-3122. doi: https://doi.org/10.20546/ijcmas.2017.608.373 